\title{
Lifestyle and Living Standards of Elderly Men in Eastern Hungary
}

\author{
Zsuzsanna Olvasztóné Balogh ${ }^{1}$, József Bognár ${ }^{2}$, \\ Judit Herpainé Lakó ${ }^{3}$, Judit Kopkáné Plachy ${ }^{2}$, \\ Magdolna Vécseyné Kovách ${ }^{4}$
}

\author{
${ }^{1}$ University of Debrecen, Faculty of Child and Adult Education, \\ Hajdúböszörmény \\ ${ }^{2}$ Semmelweis University, Faculty of Physical Education and Sport Sciences, \\ Budapest \\ ${ }^{3}$ Eszterházy Károly College, Faculty of Teacher Training and Knowledge \\ Technology, Eger \\ ${ }^{4}$ Eszterházy Károly College, Institute of Physical Education and Sport \\ Sciences
}

KEYWORDS

\begin{abstract}
This present study intends to deal with the lifestyles and living standards of elderly men. The health-related lifestyle was examined including a closer look at how elderly people value their own living standards, and how it is connected to the present state of their condition and activities. Our main goal was to highlight all lifestyle elements, because such an age, lifestyle has a decisive role in improving living standards. It seems reasonable to take several aspects - physical activity, change of lifestyle, and age differences into consideration when health-cultural behaviour is examined because all of them can influence elderly people's lifestyles and quality of life. Data were collected in eastern Hungary, in Hajdú-Bihar County, among elderly males above 60 years old $(\mathrm{N}=1,269 ; \mathrm{M}=70.23$; min: 60; $\max : 99 ; \mathrm{SD} \pm 7.095)$ through questionnaires. Our survey contained questions in three main topics: demographic profile (age, sex, education, financial status, living conditions, and occupation), health status (subjective health status, health awareness, mental health status), and health behaviour (physical exercise, smoking, and alcohol consumption). Different sub-patterns were examined during the analysis: different qualifications, age, and settlement types.

elderly people, lifestyle, health promotion, health conscious behaviour, quality of life
\end{abstract}

\section{Introduction}

Our study was inspired by those social problems caused by the aging of a population. The improving prospects for life and increasing life expectancy from birth have led to a heightened proportion of elderly around the world. Consequently, there should be a better understanding of the living conditions and prospects for healthy active living among the elderly, so comprehensive research projects need to be directed at the older population. Our present study intends to take an active part in 
this effort and explore the elderly's living, economic, and social conditions, their lifestyle, quality of life (QOL), as well as health conscious behaviour.

As defined by the World Health Organization (WHO) in Ottawa (1984), health is a resource that is needed for our everyday life and not just an object of life. According to this definition, health should be a positive notion which marks a situation characterised by physiological integrity, personal values, the ability to reach different achievements, or cope with physical, biological and social stress factors; the different roles in the family, at work and in the social community; the feeling of being well, as well as lowering the risks of different diseases and early death (Tringer 2002).

To consider health as a benefit is clearly justified by the lifestyle, due to the fact that individuals have a significant influence on their health status. Lifestyle is the central question of sociology and several experts deal with lifestyle and its constituent elements (Andorka 1997, Losonczi 1977). They generally agree that our lifestyle has two important elements: making decisions about behaviour and conditions (social, financial, and educational status), and decisions that limit our choices. From the perspective of our topic special emphasis was put on lifestyle related to health that depends on our individual, group and social situation (Pikó 2006).

Numerous studies focus on the relationship between physical exercise and health condition. It is proven that regular physical activity decreases mortality statistics, increases life span, and plays an important role in preventing disease (Gauchard et al. 2001, Pihl et al. 2002, Galetta et al. 2005, Prohaska et al. 2006). Regular physical activity has positive physiological and psychological effects as well. (Bruckner and Brown 2005).

People in their elderly years not only go through physical changes but also mental changes (Kovats 1979). When elderly are able to use their own abilities according to life situations, or perform activities in relation to their actual status, we can talk about productivity, which means a health conscious, useful and resourceful life (Iván 2004).

Lifestyle has a determining role for prolonging the number of 'years of opportunity' within one's lifespan, or extending the period of time spent in good health. Among the priorities for health development is maintaining our mental health (Kopp 2006, Sima et al. 2006). Successful ageing is strongly dependent on the individual's physical activity and mental hygiene. It is very important to avoid premature ageing by using the ageing-retarding effect of an active lifestyle (Plette and Grónai 2006). We must learn how to motivate people to establish such lifestyles that can lead them to an active old age (Majercsik 2004). The health status of the elderly must be evaluated by the correlation of social factors, financial status, family relationships, etc. (Blaskovich 2005).

Ageing is not only an unavoidable physiological process, but a serious challenge that needs to be prepared for in time (Valló 2006). Beregi (1999) believes that the extent of biological ageing - the deterioration of different physiological functions - is not exclusively genetically determined. Instead, he points to the importance of lifestyle. Successful ageing is mainly dependent on our efforts to maintain physical, mental, and social health.

The scientific health research approach to QOL, on the basis of health-related criteria - Health Related Quality of Life (HRQL). HRQL examines how we are content with our present functions (activities and way of life) (Kopp and Pikó 2006), and deals with our subjective opinions about health conditions. Good health affects our QOL: the longer one remains healthy, the better chance one has to preserve one's independence, sovereignty, and activity. Our most important task is to support the healthy and active elderly (http://ec.europa.eu/health-eu/my_health/elderly/index_hu.htm).

In our study we focus on HRQL while leaving out several factors (financial situation, place in the social hierarchy, social environment) that globally characterise QOL. Our aim is to put the emphasis on dimensions closely related to health. 


\section{Objectives}

The purpose of this study is to explore elderly people's living conditions, life-cultural behaviour, and QOL that influence successful and active ageing. Our endeavour is to examine the related issues by using sociological and gerontological research methods. Our research can be regarded as unique in Hungary; because the sample is made up only by men and the number of participants is 1269 from a county located in the eastern part of the country.

The central issue of this study is the place and role of health in the lives of elderly men living in eastern Hungary. Educational level, age, place of life, financial situation, social environment, health conditions, and an active life are important and influencing factors of health-cultural behaviour. QOL was also examined.

\section{Hypotheses regarding lifestyle and health conscious behaviour:}

$\mathbf{H}_{\mathbf{1}}$ : We assume that elderly men are generally aware of the criteria of healthy lifestyle; however, this is not reflected in their life. Furthermore, we assume that as a result of changes in their social roles, several undesirable forms of behaviour and risk factors get into the forefront in their lives and they tend to take up harmful and deviant forms of behaviour that endanger their health.

$\mathbf{H}_{2}$ : We assume that doing regular exercises has a positive effect on the health condition of elderly people and the number of diseases is lower among those do regular exercises.

$\mathbf{H}_{3}$ : We assume that elderly people with higher qualifications or living in a town have more positive attitudes towards healthy lifestyle and their health condition is more satisfactory than elderly men with lower qualifications or living in a village.

\section{Hypotheses regarding QOL:}

$\mathbf{H}_{4}$ : We assume that the general disposition of the elderly (men between 60 and 69) is influenced more by their health condition (health problems hindering their everyday life) than in the case of those in the third stage of life.

$\mathbf{H}_{5}$ : We assume that, due to an existing connection between the self-judgement of one's general disposition and family conditions; due to this connection, that those who live with a partner or in a family, who have higher qualifications, and live in a town feel better than those who live alone, have lower qualification, or live in a village.

\section{Methods}

\subsection{Sample}

In order to discover the QOL and lifestyle of the elderly, a survey was conducted in HajdúBihar County. According to the criteria set out by the World Health Organization (WHO), anyone past the age of 60 is considered elderly, thus anyone belonging to the age group of over 60 years old qualifies. Both at a national and county level the proportion of elderly males are $39 \%$ against $61 \%$ females. That is why we feel justified in having applied expert sampling methods when choosing the individuals for the survey (Babbie 1998). Among the residents of various towns and villages in eastern Hungary we chose elderly men. Our goal was to reach all elderly males through the different club systems for the retired in the county. A self-made questionnaire was used concerning changes in living conditions, everyday and leisure activities, mental status, health conscious behaviour and a subjective judgement of health status. In addition, a WHOQOL-OLD questionnaire was used, which was compiled by the WHOQOL-OLD international workgroup (Kullmann and Harangozó 1999, Tróznai and Kullmann 2007). The WHOQOL-OLD questionnaire contains the following facets: perception (F25); autonomy (F26); activities of past, present and future (F27); sociability (F28); attitudes toward death (F29); intimacy (F30). Each facet contains four questions and it was examined by a 5-grade Likert scale. 
1,269 individuals were interviewed by socio-pedagogy students of the Faculty of Child Education and Adult Training of Debrecen University.

\subsection{Demographic factors, parameters}

Every individual of the sample is male $(\mathrm{N}=1269, \mathrm{M}=70.23 \pm 7.095, \min =60, \max =99$ years $)$. The summary of the educational level can be seen in table 1 .

Table 1. Respondent's level of education

\begin{tabular}{|c|c|c|}
\hline Education & $\%$ & $\%$ \\
\hline 8 years of primary education & 28,6 & \multirow{2}{*}{ P: 42.3} \\
\hline Less than 8 years of primary education & 13,7 & \\
\hline Secondary grammar school & 14,3 & \multirow{2}{*}{ S: 44.4} \\
\hline Vocational school & 30,1 & \\
\hline Secondary technical school & 5,2 & \multirow{3}{*}{$\mathbf{H}: 13,3$} \\
\hline College & 4,9 & \\
\hline University & 3,2 & \\
\hline
\end{tabular}

The sample was divided into different groups according to age, qualification, and settlement type. Regarding age: three, mainly equivalently numbered groups, were chosen (Table 2).

Table 2. Summary of the criteria of our analysis and grouping

\begin{tabular}{lll}
\hline \multicolumn{3}{c}{ Criteria of our analysis and grouping } \\
Age & Level of education & Place of living \\
\hline Group 1: $60-65 \mathrm{yr}$ & $\mathbf{P}-$ primary education & $\mathbf{T}-$ town \\
$(\mathrm{N}=413, \mathrm{M}=63,33 \pm 1,24)$ & $(\mathrm{N}=532)$ & $(\mathrm{N}=578)$ \\
Group 2: $66-72 \mathrm{yr}$ & $\mathrm{S}-$ secondary education & $\mathbf{V}-$ village \\
$(\mathrm{N}=457, \mathrm{M}=68,76 \pm 1,95)$ & $(\mathrm{N}=558)$ & $(\mathrm{N}=691)$ \\
Group 3: over $73 \mathrm{yr}$ & $\mathbf{H}-$ higher education & \\
$(\mathrm{N}=399, \mathrm{M}=79,09 \pm 4,9)$ & $(\mathrm{N}=579)$ & \\
\hline
\end{tabular}

\subsection{Data processing, data analysis}

Data were analysed by SPSS 17.0 for Windows (Falus and Ollé 2002) with descriptive statistic, crosstabs, and analysis of variance (ANOVA). Spearman's and Pearson's correlation was used, the significant level was $\mathrm{p}<0.05$.

\subsection{Examination of elderly men's lifestyle}

In order to examine the lifestyle, the health conduct, and the subjective judgement of the health status of elderly men, a self-made questionnaire and the WHOQOL-OLD questionnaire were analysed. The socio-demographic background (age, education, family status, types of disease occurring, number of years of retirement, change in living conditions since retirement) was analysed, too.

There were questions concerning the self-evaluation of health status, everyday activities, the subjective judgement of general condition, attitudes toward health, the medical advantages of physical activity, QOL, and health conscious behaviour - including physical activity.

\section{Results}

In strong correlation with the level of education, $86.4 \%$ used to be blue collar workers and $13.6 \%$ white collar workers before retirement. Education and occupation show positive correlation $(\mathrm{r}=$ $0.576, \mathrm{p}=0.000)$. The number of years that were spent working is 37.89 years $(\mathrm{min}=10, \max =58$, 
$\mathrm{SD} \pm 6.463$ ). $28 \%$ of the respondents worked for $35-39$ years, while $43.1 \%$ worked for $40-45$ years. Regarding family status: $64.7 \%$ are married, $24.6 \%$ are widowers, $7 \%$ are divorced, and $3.7 \%$ are still single.

\subsection{Groups of diseases}

The main disease was hypertension, which was followed by locomotors disorders (Figure 1).

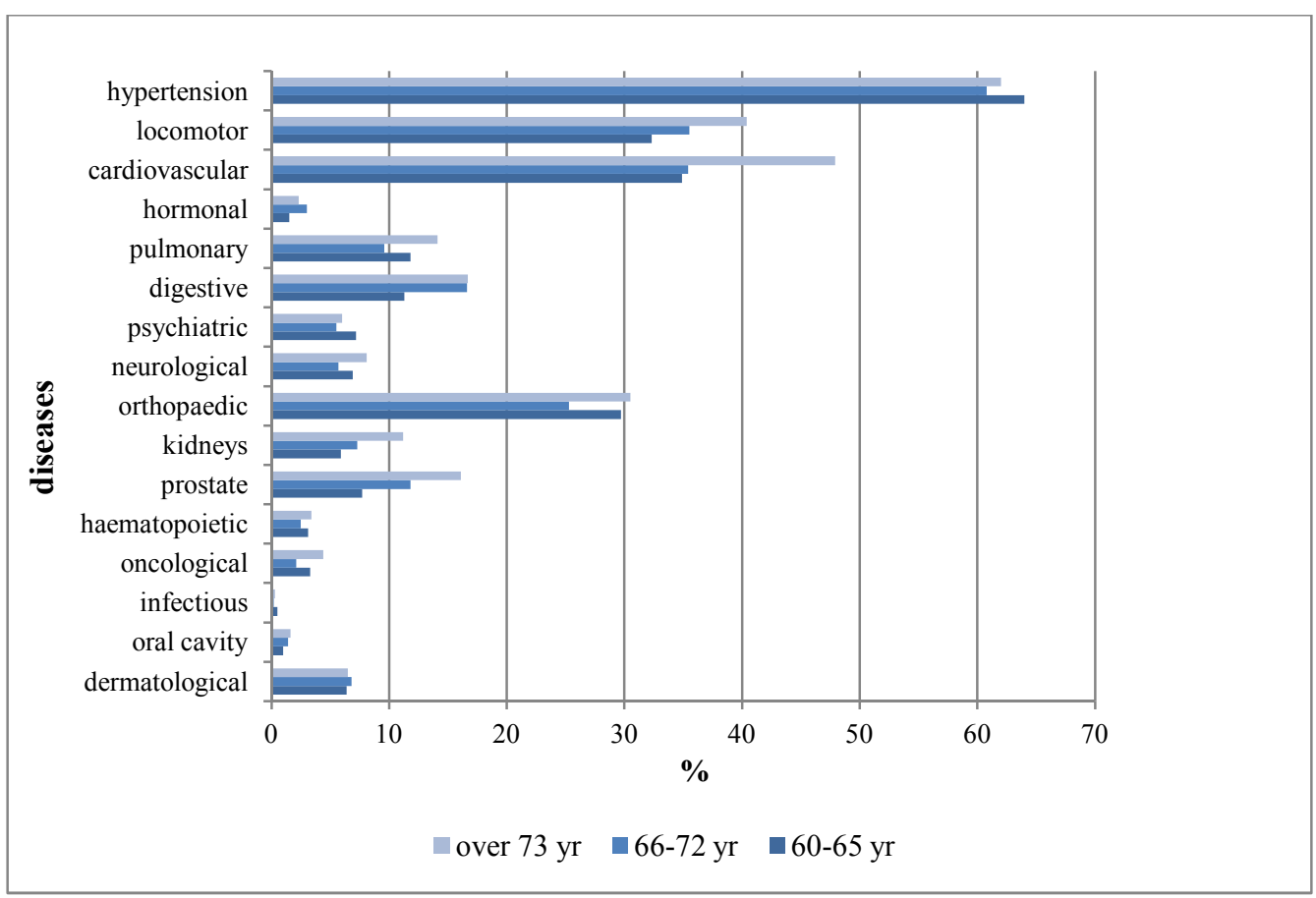

Figure 1. Frequency of diseases in the different age groups

When comparing the three age groups, increases in hypertension, hormonal dysfunctions, and different diseases of the leg could be observed. Age is a determining factor of kidney $(\mathrm{F}=3.965$, $\mathrm{p}=0.019)$, prostate $(\mathrm{F}=6.665, \mathrm{p}=0.001)$ and cardiovascular diseases $(\mathrm{F}=9.102, \mathrm{p}=0.000)$. Significant differences were found in the case of two variables regarding both educational levels and place of living. The number of dermatological problems $\left(\mathrm{Chi}^{2}=6,916, \mathrm{p}=0,031\right)$ and psychiatric disorders $\left(\mathrm{Chi}^{2}=11.965, \mathrm{p}=0,003\right)$ are significantly lower among men with high qualifications compared to those in the other two groups. When comparing our results on the basis of the respondents' places of living, those living in villages more frequently suffer from various leg problems $\left(\mathrm{Chi}^{2}=4,531 \mathrm{p}=0,033\right)$ and have higher deformations in the oral cavity $\left(\mathrm{Chi}^{2}=6,420 \mathrm{p}=0,009\right)$ than those living in towns.

In our sample, $60 \%$ live in a whole family, $27.2 \%$ are either self-supporting or live on their own, $10.7 \%$ live together with some other family members (relatives, children, siblings), and $21 \%$ have entered into a life support contract. When comparing the results of type of living, significant differences were found between the age groups $\left(\mathrm{Chi}^{2}=54,014, \mathrm{p}=0,000\right)$, the educational levels $\left(\mathrm{Chi}^{2}=37,796, \mathrm{p}=0,000\right)$ and settlement types $\left(\mathrm{Chi}^{2}=16,815, \mathrm{p}=0,005\right)$. The proportions of the individual variables are shown in figure 2 below: 


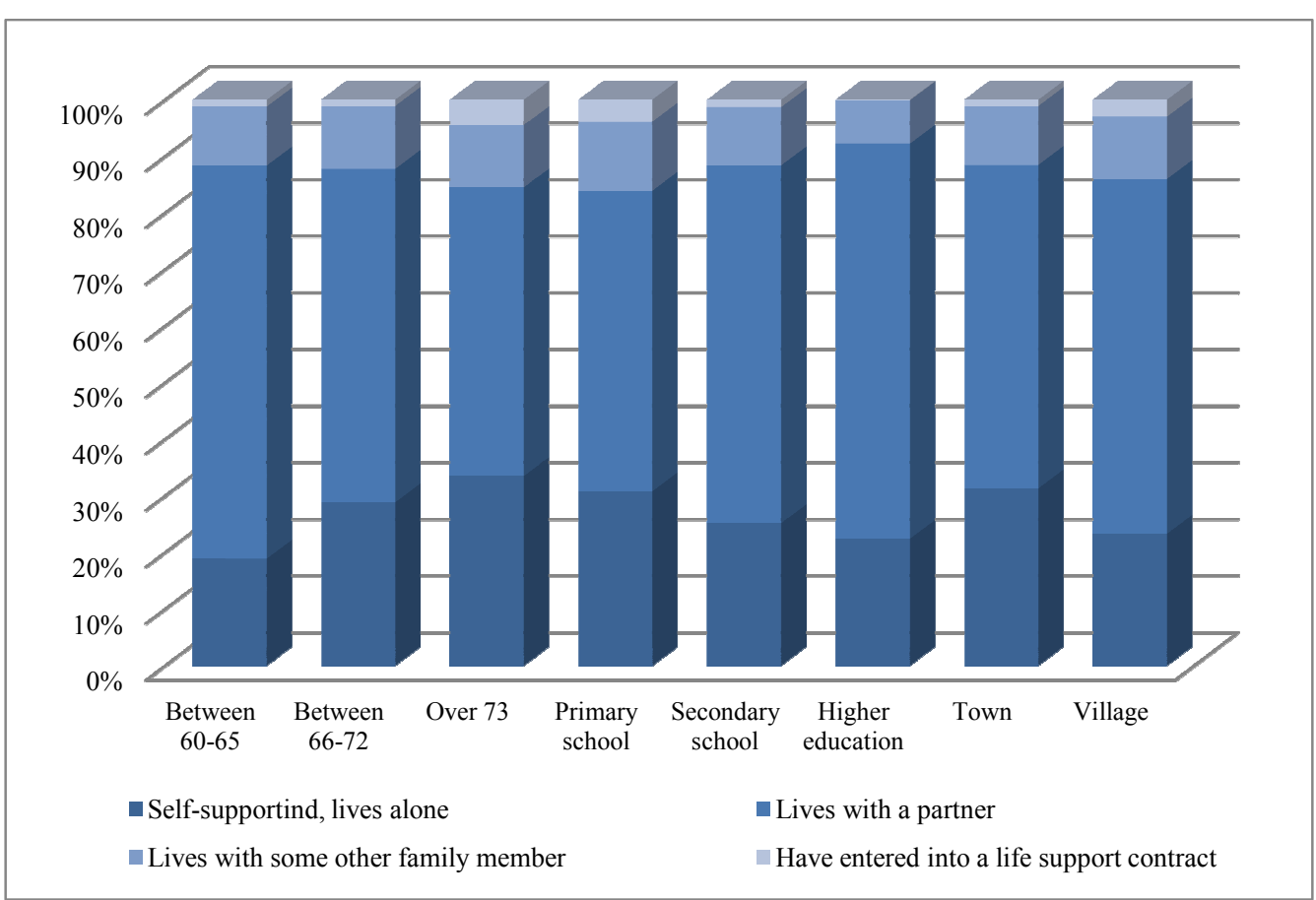

Figure 2. Distribution of family circumstances

\subsection{Subjective judgement of health status}

When asked for a subjective judgement of health status, $10.8 \%$ of all respondents consider themselves to be healthy, $35.4 \%$ receive constant medical treatment, $50.1 \%$ suffer from minor ailments, and $3.5 \%$ have undergone various surgical operations.

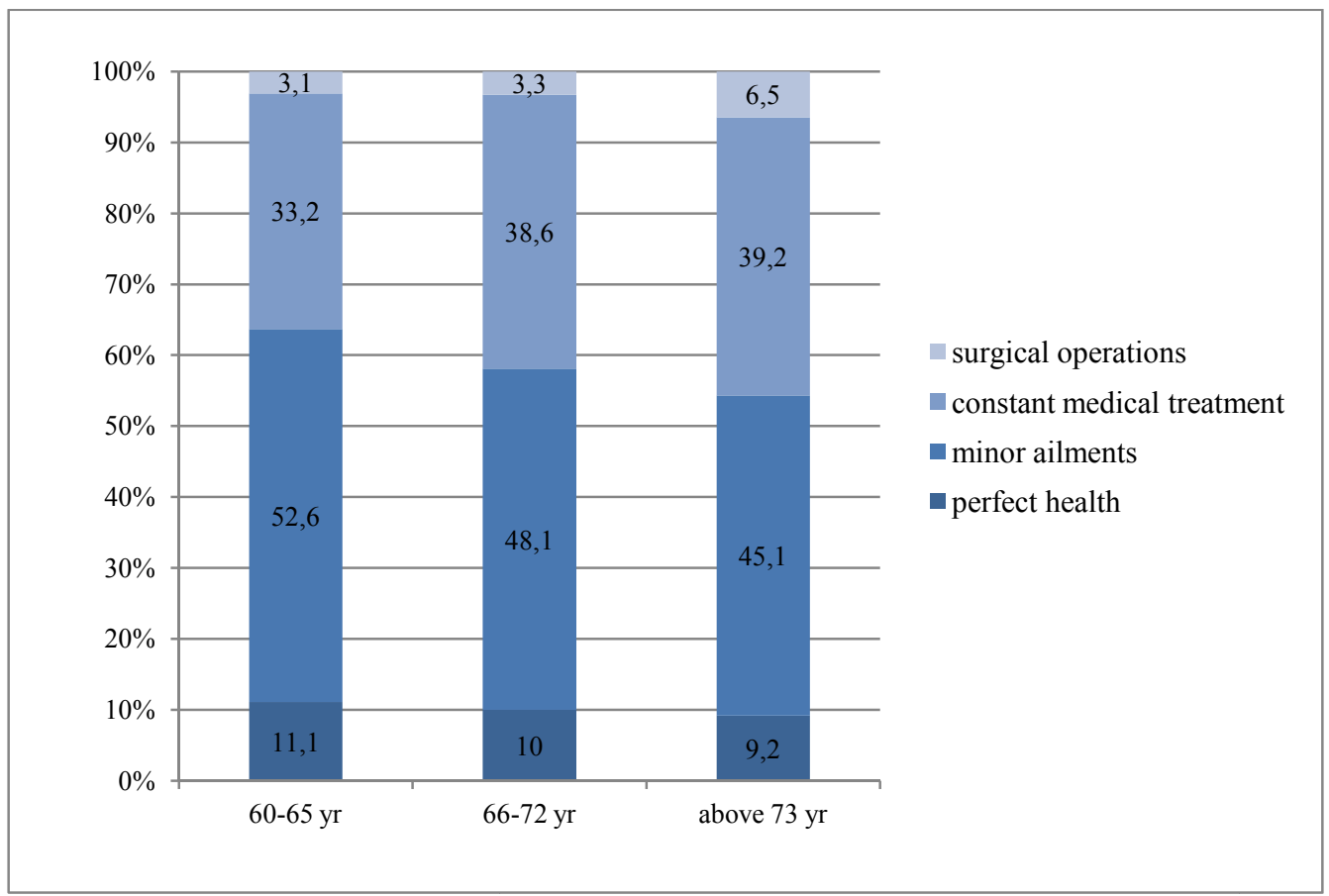

Figure 3 . Health status by age distribution

Differences were found between those considering themselves healthy in the groups set up on the basis of different educational levels $\left(\mathrm{Chi}^{2}=21,378, \mathrm{p}=0,006\right)$. Elderly men with higher qualifications (university, college) consider themselves healthier than those being in the two other groups (17.7\%). We found that the proportion of those receiving constant medical treatment is lower 
in this group (27.2\%). Regarding the different settlement types, no significant differences were found regarding health status.

The definition of good health was examined by six parameters: good health $(62.1 \%)$, pleasure (19.2\%), and happiness (18.7\%). As a result of comparing differences between the different age groups, no significant values were found. To be happy is an important component of good health in men having higher qualifications $\left(\mathrm{Chi}^{2}=25,704, \mathrm{p}=0,012\right)$. For elderly men living in villages the category of to enjoy the life seemed to be the most significant component of good health $\left(\mathrm{Chi}^{2}=14,440\right.$ $\mathrm{p}=0,013)$.

\subsection{Health conscious behaviour}

Health conscious behaviour was examined by healthy and harmful habits. $69.8 \%$ of the sample does not smoke. In the case of alcohol consumption: casual drinkers (44\%), teetotallers (35.6\%), while the proportion of regular consumers is $20.0 \%$. We found significant differences among the different age groups and educational levels. The proportion of smokers $\left(\mathrm{Chi}^{2}=41,019, \mathrm{p}=0,000\right)$ and regular alcohol consumers $\left(\mathrm{Chi}^{2}=27,645, \mathrm{p}=0,001\right)$ are significantly higher in the second age group. Regarding educational levels, the number of smokers significantly increases in the group $\mathrm{S}$ compared to $\mathrm{P}$ $\left(\mathrm{Chi}^{2}=18,851, \mathrm{p}=0,016\right)$ and there is an increase in the proportion of casual drinkers as well $\left(\mathrm{Chi}^{2}=29,122, \mathrm{p}=0,000\right)$. Regarding the different places of living, no significant differences were found in smoking habits and alcohol consumption.

Examining physical exercise as a main factor of a healthy lifestyle, athletic habits at an early age were to be explored. The results showed that $45.3 \%$ of the sample did not do any sports when they were young; the proportion of those who used to do casual sports activities was $31.0 \%$, while regular sports activities were done by $22.6 \%$ of all respondents. Football was the most popular (16\%), followed by other ballgames (handball, basketball, and volleyball $12.8 \%$ ), athletics $(9.2 \%)$ and swimming (8.3\%). Combat sports were less popular (wrestling, boxing, judo and karate, $5.4 \%$ ), and similarly tennis and table tennis (4.6\%). A wide variety of different sports appeared in insignificant measure (0.8-1.4\%), such as gymnastics, cycling, parachuting, skating, shooting, kayaking, canoeing, weightlifting, horse riding, trekking, and fencing. The proportion of those doing sports regularly and casually, now and earlier, decreases both in the second and third age group $\left(\mathrm{Chi}^{2}=44,044, \mathrm{p}=0,000\right.$; $\left.\mathrm{Chi}^{2}=20,986, \mathrm{p}=0,000\right)$. We can see values regarding sport habits and qualifications or settlement type (P: $\mathrm{Chi}^{2}=104,328, \mathrm{p}=0,000 ; \mathrm{S}: \mathrm{Chi}^{2}=36,453, \mathrm{p}=0,000 ; \mathrm{T}: \mathrm{Chi}^{2}=28,854, \mathrm{p}=0,000 ; \mathrm{V}: \mathrm{Chi}^{2}=18,228$ $\mathrm{p}=0,003)$.

\subsection{Quality of Life}

Statistical differences of WHOQOL-OLD can be seen in table 3.

Table 3. Descriptive statistic of WHOQOL-OLD questionnaire

\begin{tabular}{lll}
\hline Questions & Facets & Mean \pm SD \\
\hline F25 & Perception & $2,60 \pm 0,611$ \\
F26 & Autonomy & $3,43 \pm 0,657$ \\
F27 & Activities of past, present and future & $3,28 \pm 0,660$ \\
F28 & Sociability & $3,45 \pm 0,657$ \\
F29 & Attitudes toward death & $2,46 \pm 1,025$ \\
F30 & Intimacy & $3,24 \pm 1,05$ \\
\hline
\end{tabular}




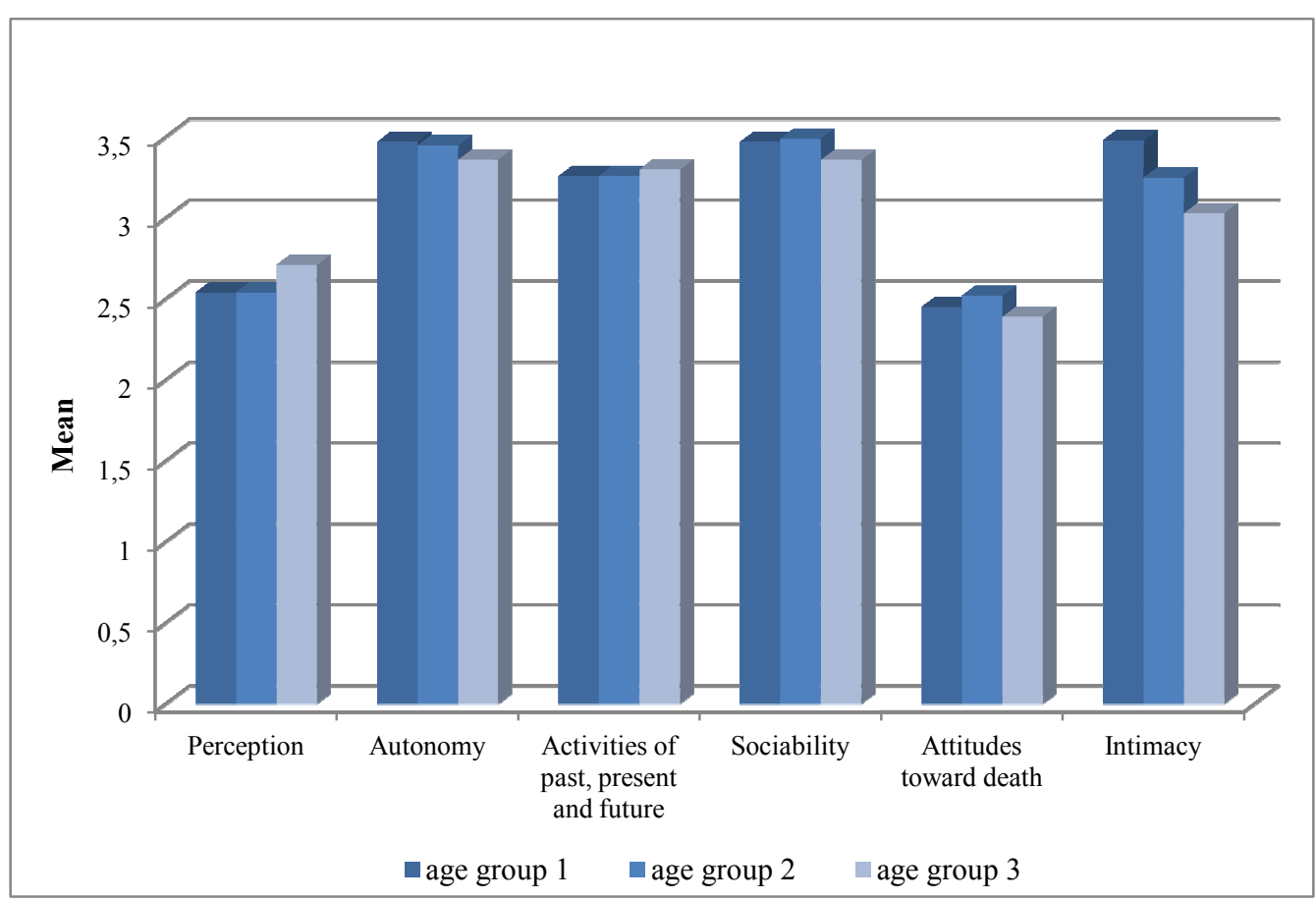

Figure 4. Connections between QOL and age groups

As it can be seen in figure 4, there are significant differences in the indices of Perception $(\mathrm{F}=10,418, \mathrm{p}=0,000)$ and Intimacy $(\mathrm{F}=18,068, \mathrm{p}=0,000)$.

Connections between QOL and education can be found in figure 5 .

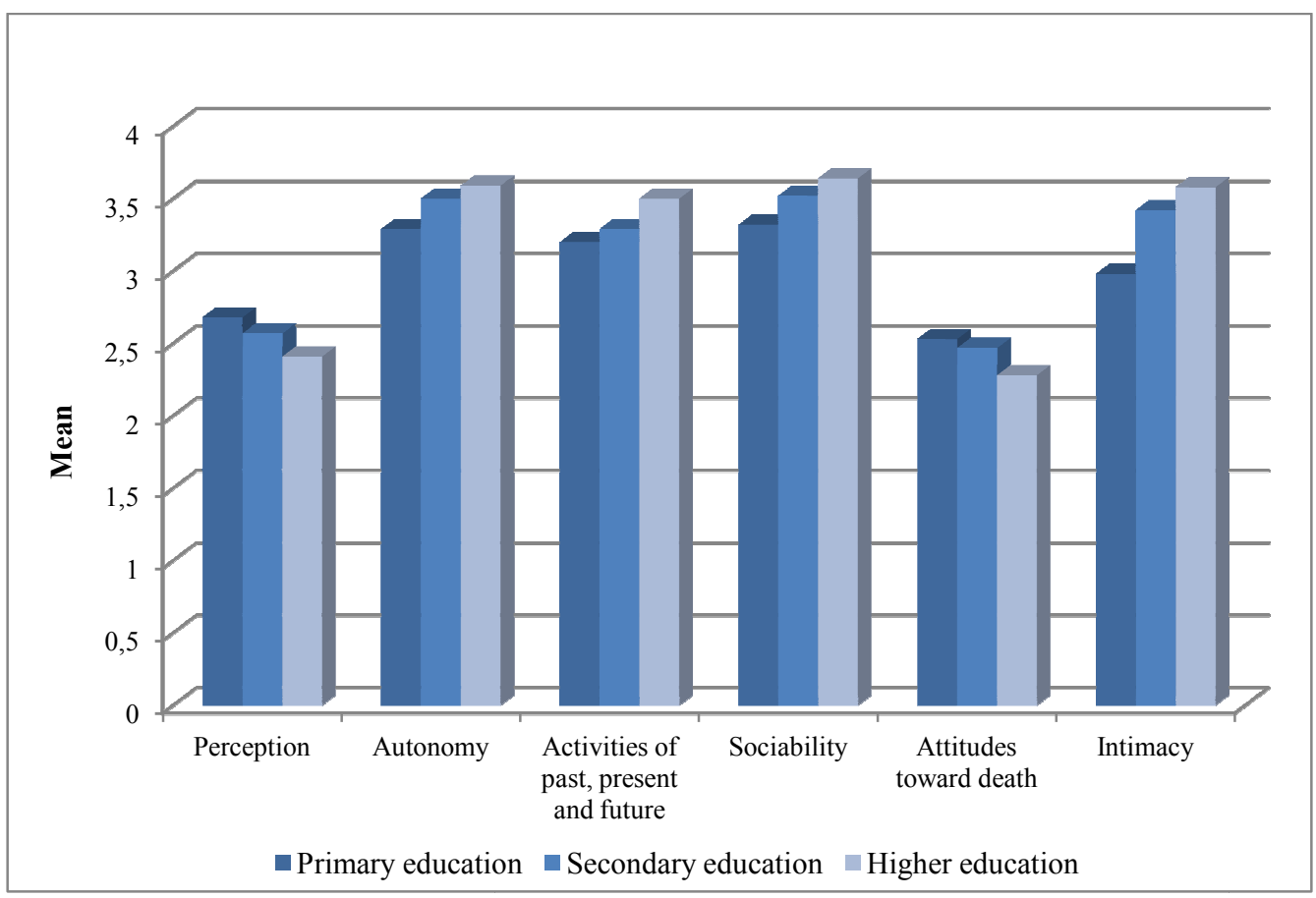

Figure 5. Connections between QOL and education levels

On the basis of the different levels of education, there are significant differences in $p \leq 0,05$; significance level in Perception ( $\mathrm{F}=12,996)$, Autonomy $(\mathrm{F}=19,445)$, Activities of the past, present and future $(\mathrm{F}=12,810)$, Sociability $(\mathrm{F}=19,894 ; \mathrm{F}=32,804)$ and Intimacy $(\mathrm{F}=32,804)$. 
The results of QOL and settlement types can be found in figure 6 .

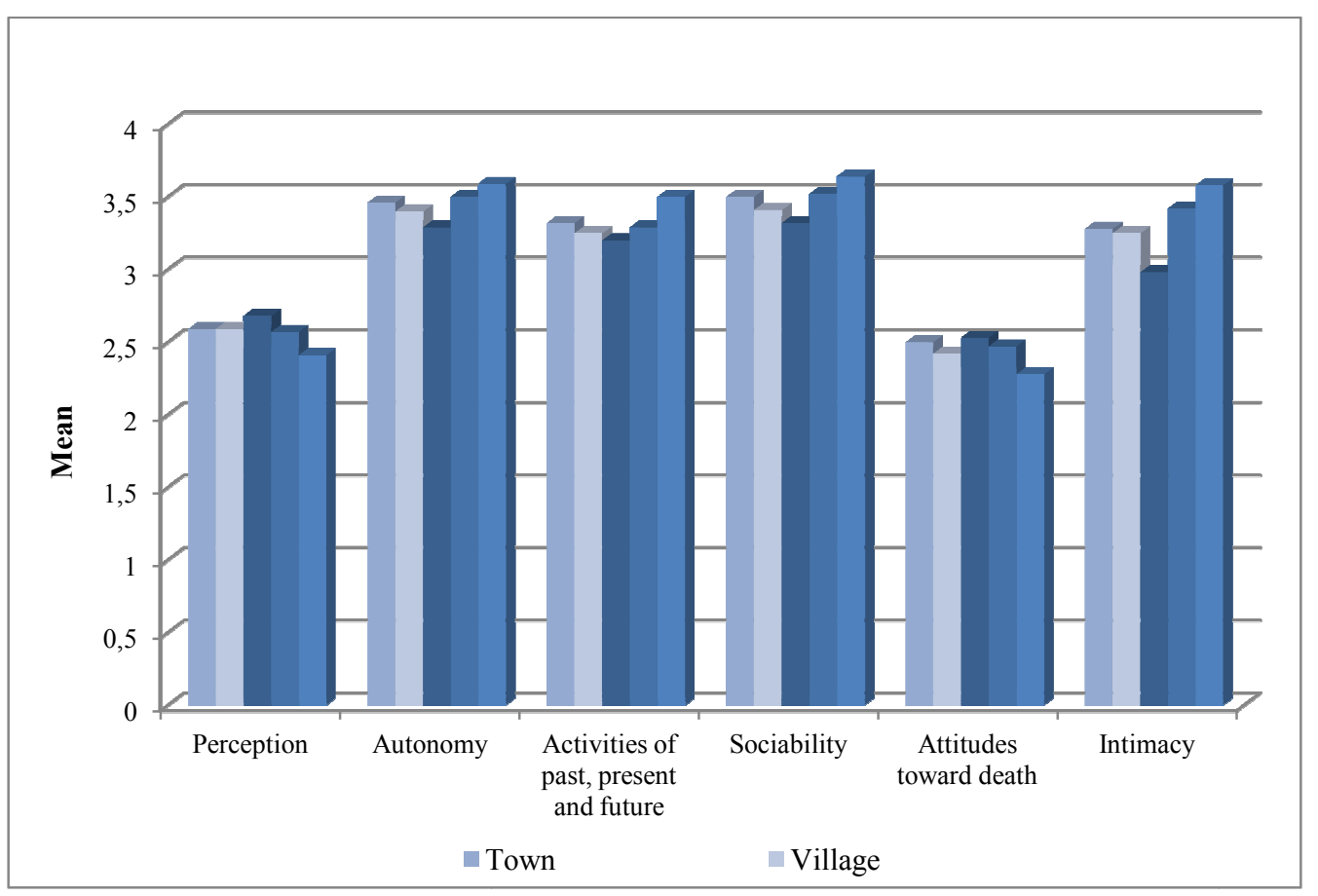

Figure 6. Indices of quality of life on the basis of settlement types

After having compared the results in settlement types and QOL, significant differences were found in Activities of past, present and future and Participation in the community ( $\mathrm{F}=3,989 \mathrm{p}=0,046$; $\mathrm{F}=4,608 \mathrm{p}=0,032$ ).

\section{Conclusions}

In analysing the specialised literature, a great number of national studies on lifestyle, QOL, and health conscious behaviour of the elderly could be found (Majercsik 2004, Ivan 2005, Kovacs 2006, Olvasztone et al. 2007). In our study we provided information about the Hungarian elderly male population. The forms of harmful behaviour (smoking, alcohol consumption) become significantly more frequent in the years right after retirement. The frequency of various diseases is lower among elderly men who do regular physical activity. Elderly men living in towns, or with higher qualifications, have more positive physical activity habits. Regarding physical activity, highly qualified elderly men also show significant differences compared to the other groups since they consider physical activity as an important daily activity in greater proportion to an men with lower qualifications.

Our study reinforces the national results according aging progresses and health deterioration (Monostori 2009). Changes in physical condition influence the mental situation of individuals as well. Almost two-thirds of all respondents consider their general condition as being good; almost half of them were well balanced. Considering the results, our sample said his future is uncertain, similar to other national surveys (Tróznai and Kulmann 2007). One-third of the respondents said that living conditions had deteriorated significantly since retirement. Similar values can be found in Dobossy et al. (2003). Elderly men living in a partnership judged their general disposition to be much better than those living alone.

The deterioration in QOL going along with the passing of years influences general health and mental status. The appearance of several diseases becomes characteristic: first of all, blood pressure problems that are in connection with the cardiovascular and coronary heart diseases, and locomotors 
disorders. A lack of friends and immediate family members can make elderly people lonely. Changes in physical condition also affect the mental situation of elderly people. All of the above influence the examined elderly men's general disposition and mood.

As a result of our research it can be stated that the most important factors influencing one's quality of life at old age are the following:

- physical and mental condition and their effect on activities of daily living,

- maintaining the activity and participation in social community,

- feelings of usefulness in everyday life,

- feelings of companionship (family, friends, neighbours),

- adaptability, harmony,

- $\quad$ positive and negative life events during the life of the individual.

Summarizing our results and findings, we can declare that useful information was received about living conditions, lifestyle and QOL of elderly men, even for the science of gerontology.

\section{REFERENCES}

Andorka, R. (1997). Bevezetés a szociológiába /Introduction into sociology/. Budapest: Osiris Kiadó.

Babbie, E. (2001). A társadalomtudományi kutatás gyakorlata/The practice of the social science/. Budapest: Balassi Kiadó.

Beregi, E. (1999). Egészségben megöregedni /Healthy aging/. Budapest: Medicina Könyvkiadó Rt.

Blaskovich, E. (2005). Az EU-konform komplex idögyógyászati modell hazai tapasztalatai/The Hungarian observations of complex EU conform time model/. Hippocrates 2, 130-134.

Brukner, P.D. \& Brown, W.J. (2005). Is exercise good for you? Medical Journal of Australia, 183, 10, 538-541.

Dobossy, I., S. Molnár, E., Virágh, E. (2003). Öregedés és társadalmi környezet /Aging and social environment/ (pp. 136-160). Műhelytanulmányok 3. Budapest: KSH Népességtudományi Kutatóintézet.

Falus, I., Ollé, J. (2000). Statisztikai módszerek pedagógusok számára /Statistical methods for teacher/. Budapest: Okker Kiadó.

Galetta, F., Franzoni, F., Femia, F.R., Rocella, N., Pentimone, F. and Santoro, G. (2005). Lifelong physical training prevents the age-related impairment of heart rate variability and exercise capacity in elderly people. Journal of Sports Medicine and Physical Fitness, 45(2), 217-221.

Gauchard, G.C., Jeandel, C. \& Perrin P.P. (2001). Physical and sporting activities improve vestibular afferent usage and balance in elderly human subjects. Gerontology, 47, 263-2270.

Ivan, L. (2004). Öregedés: örök ifjúság? /Aging: forever young/. Mindentudás Egyeteme $\mathrm{http}: / /$ mindentudas.hu/eloadasok/szemeszter/itemlist/extrafield.html?extrafield $=2 \&$ extrafieldval ue $=4 \&$ theme $=$ eloadasok\&page_title=IV.+szemeszter.

Ivan, L (2005). Az idősödés és időskor, mint az edzettség próbája /Aging, third age is the test of sport level/. In J. Gy. Némethné (Ed.), Aktivitás - mozgás - sport a harmadik életszakaszban (pp. 7-18). Györ: Szenior Könyvek.

Kopp, M. (2006). A lelkiállapot és az egészség összefüggései /The connections between mood and health/. In R. Ádány (Ed.), Megelözö orvostan és népegészségtan (pp. 516-522). Budapest: Medicina Könyvkiadó Zrt.

Kopp, M., Pikó, B. (2006). Az egészséggel kapcsolatos életminőség pszichológiai, szociológiai és kulturális dimenziói /Psychological, social and cultural dimensions of health related quality of life/. In M. Kopp, M. E. Kovács (Eds.), A magyar népesség életminösége az ezredfordulón (pp. 10-17). Budapest: Semmelweis Kiadó.

Kovács, K. (2006). Egészség-esélyek/Chances for health/. KSH Népegészségtudományi Kutatóintézet Életünk fordulópontjai, Mühelytanulmányok 5.

Kováts, F. (1979). Egészséges élet - derüs öregség /Healthy living - cheerful aging/. Budapest: Medicina könyvkiadó.

Kullmann, L., Harangozó, J. (1999). Az Egészségügyi Világszervezet életminőség vizsgáló módszerének hazai adaptációja /The Hungarian adaptation of WHO quality of life models for health examinations/. Orvosi Hetilap, 140, 1947-1952.

Losonczi, Á. (1977). Az életmód az időben, a tárgyakban és az értékekben/Lifestyle in time, in objects and in values/. Budapest: Gondolat Kiadó.

Majercsik, E. (2004). Idösek a mában /Elderly today/. http://phd.om.hu/disszertációk/értekezések. 
Monostori, J. (2009). Öregedés /Aging/. In J. Monostori, P. Öri, E. S. Molnár, Zs. Spéder (Eds.), Demográfiai portré (pp.79-88). Budapest: KSH Népességtudományi Kutató Intézet.

Olvasztóné, B.ZS., Huszár, A., Konczos, Cs. (2007). Az egészségkulturális magatartás és elemzése /Assessment of health conscious behavior/. Kalokagathia, XLV, 1-2, 111-125.

Ottawai Karta (WHO)(2010). http://www.who.int/hpr/NPH/docs/ottawa_charter_hp.pdf.

Pihl, E., Matsin, T., Jürimae, T. (2002). Physical activity, musculoskeletal disorders and cardiovascular risk factors in male physical education teachers. Journal of Sports Medicine and Physical Fitness, 42(4), 466-471.

Pikó, B. (2006). Orvosi szociológia /Medical sociology/. Budapest: Medicina Könyvkiadó Zrt.

Plette, R., Grónai, É. (2006). A lelki egészség kérdései Magyarországon/Questions about mental health/. Foglalkozás-egészségügy, 1, 24-33.

Prohaska, T., Belansky, E., Belza, B., Buchner, D., Marshall, V., McTigue, K., Satariano, W., Wilcox, S. (2006). Physical Activity, Public Health, and Aging: Critical Issues and Research Priorities. The Journal of Gerontology, 61B(5), 267-273.

Sima, Á., Pikó, B., Horváth J.K. (2006). A mentálhigiéné, mint egészségfejlesztési prioritás: középiskolások lelki egészségének, életmódjának kockázati magatartásának vizsgálata /Mental hygiene as topics of improving health: assess the lifestyle and risk factors in secondary schools/. Egészségfejlesztés, 1-2, 33-37.

Tringer, L. (2002). A mentális betegségek megelözésének és ellátásának korszerü szemlélete (The modern approach for prevention and medical attendance of mental diseases). Orvostovábbképzö Szemle IX. 9. 12-21.

Tróznai T., Kullmann L. (2007). Az idős emberek életminőségének és idősödéssel kapcsolatos attitüdjeinek vizsgálata /Assessment of elderlies' quality of life and their attitudes toward aging/. LAM, 17, 2, 137-143.

Valló, Á. (2006). Együtt élni az öregedéssel /Live together aging/. Patika magazine, 5.

World Health Organization. Constitution. WHO, 1984.

http://ec.europa.eu/health-eu/my_health/elderly/index_hu.htm

AUTHOR'S ADDRESS: Zsuzsanna Olvasztóné Balogh

University of Debrecen

Faculty of Child and Adult Education, Hajdúböszörmény

H-4220 Hajdúböszörmény, Désány út. 1-9

Hungary

Email: olvasztone@ped.unideb.hu 